For the first time in the history of the world, delegates of, and advisers to, the various Governments concerned have met together in council, armed with the knowledge and experience of the disastrous results which may follow the uncontrolled actions of blundering and profiteering man, in order to devise reciprocal measures designed to prevent such actions in the future and to conserve for all time, in so far as it is possible, the natural features and economic possibilities of a great continent.

It is true that as yet only the most elementary steps have been taken, but the important point is that a beginning has been made and definite steps in the right direction taken. Doubtless as more conferences are held, the necessity for enlarging the scope of the term 'flora' will be realized, until it comprehends the consideration of the far wider question of the preservation of the balance not only between forested and unforested areas, but also of the proper conservation of those essontial areas which act like sponges for the storage of water and control the water supply of those areas of land which can be properly utilized for agricultural purposes.

In this connexion, the deliberations and actions of future conferences will surely profit by the gross mistakes which were originally made in developing the agricultural resources of such countries as the United States of America, Australia and New Zealand. In America, for example, we now know that as a consequence of ignorant and thoughtless drainage schomos, thousands of square miles of good land have literally 'gone with the wind'; while in Australia the over-zealous clearing away of forested areas has upset the biological balance of Nature, with the inevitable and consequential appearance of various plagues of an animal or vegetable nature which may, and have, cost millions of good money to combat. We would venture, therefore, to make the suggestion that the work of future conferences would be enormously benefited and its scope very profitably enlarged by the inclusion in its general body of national advisers of a sufficiency of forestry experts.

PERCY R. LOWE.

\title{
The Morphology of the Carpel
}

A $\mathrm{N}$ important contribution to the vexed question of carpel morphology has recently been published in La Cellule $(47,287-452$; 1938) by Prof. V. Grégoire, the late professor of botany at the University of Louvain (see NATURE, 143, 400 ; 1939); it is characterized by the remarkable number of fine illustrations, mainly photomicrographs (no fewer than 252 in fourteen plates). The problem is approached from the point of view of development, and it is more than a coincidence that both Prof. McLean Thompson, of the University of Liverpool, and Prof. Grégoire, approaching it from this angle, reject decisively the classical theory that the carpel may be regarded as a modified leaf. The "state of flowering" of McLean Thompson and the "reproductive apex" of Grégoire necessitate a new terminology to interpret their characteristics of form, as both authors are agreed that analogies from vegetative organizations are misleading and quite unjustified.

We owe to previous papers by Prof. Grégoire and his colleagues the concept of the vegetative growth apex as establishing, in successive time intervals, or plastochrones, a series of transversely expanded foundations, which are components of the axis (the soubassements), upon which are then raised new foliar primordia. This mode of growth necessitates a meristem organized in depth and constructed, in modern terminology, of a tunica overlying a corpus, both of which have a meristematic nature and contributo to these succossive units of shoot organization.

Prof. Grégoire points out that noithor tunica nor corpus can be identified at the reproductive apex. There is a superficial meristem of uncertain depth, covering both the summit and the flanks of the apex; but this is not identified as a tunica because of the frequency with which periclinal divisions alternate with anticlinal, thus adding to the depth of parenchyma below. Below it there is no meristematic corpus at all, but a parenchymatous mass homologous with the pith. The superficial meristematic layer can add no units of constmuction to the shoot; the floral parts are simply emergences from it with no axial founda- tion such as is present with a leaf primordium. Not even the sepals are regarded now, in contradistinction to Grégoire's earlier views, as homologues of foliar structures.

The insertion of each new foliar primordium becomes the centre of a new impetus to procambial activity, the leaf-trace system of the new unit thus contributing basifugally to the vascular tracts spreading into the leaf and basipetally to the trace system linking this with the axis. In the reproductive axis, this basipetal contribution to procambial development is missing ; from a procambial 'magma' often of considerable extent and sometimes spread solidly across the base of the reproductive axis, cordons of procambium, often anastomosing or bifurcating freely, spread basifugally into peduncles and then into floral parts; but there is no suggestion that this procambial activity contributes basipetally to an enlargement of the vascular system bolow the reproductive axis.

The two types of growth, the vegetative and reproductive, are fundamentally distinct and not reducible to a common plan. A reproductive apex does not even develop out of a vegetative apex by its gradual modification; it arises as a lateral growth on the side of the vegetative apex that it displaces, and if subsequent proliferation shows a return to foliar emergences then a vegetative apex has re-arisen adventively on a reproductive axis. Such a reproductive axis, always a layer of meristem tissue upon a parenchymatous plinth, still capable of some growth and extension (the porte-méristème of Grégoire) may be used up entirely in the production of floral parts, it may dichotomize by the development of a central groove, or divide into more fragments as the result of moro grooves developing. Its floral members arise without plastochronic intervals and theso members are local products of a portion of the meristom without the tendency to bilateral spread around the axis characteristic of the foliar primordium.

Grégoire distinguishes two types of carpels among those now described: the Ranunculus type, in which a 
transverse or tangential slit separates a dorsal upcurving and enclosing segment from a ventral, on the abaxial face of which a single ovule arises in the median position; and the Aquilegia-Rubus type, in which a very narrow radial slit is present between two lateral walls, joined external by a strongly developed dorsal wall which runs up into the stigma. This type gives the follicle which is the basis of the foliar theory of the carpel, but Grégoire points out that the thin radial slit first formed does not agree at all with the concept of two incurving leaf margins joining to give the ventral suture. In the Aquilegia. Rubus type this thin slit later expands at its outer margin to give the cavity on which are formed the ovules, few in number but necessarily lateral in position, but in Papaver, Butomus, etc., the whole surface of the slit is meristematic and active in the production of ovules. Prof. Grégoire shows that perigyny is a natural development of the outer margin of the parenchymatous plinth upon which the reproductive meristem is carried; he thus excludes its interpretation as a concrescence of sepals. $\mathrm{He}$ emphasizes that from the new point of view perigynous forms are not to be interpreted as intermediate between epigynous and hypogynous.

The whole paper is a vigorous challenge to classical morphology in a field where there has been much activity in recent years. Prof. Grégoire refused to consider the palæobotanical contributions to this problem and the cupule theory that has thus emerged; but apart from this there is a very full discussion of the bearing of his most recent observations upon the diverse interpretations that have been given to the carpel.

\section{The S.S. Archimedes}

$\mathrm{I}^{\mathrm{N}}$ March 1839, the historic little screw-driven vessel S.S. Archimedes bagan her trials in the River Thames. A month or two later she visited Portsmouth, and afterwards made voyages around the coasts of Great Britain and to Holland and Portugal. She was the first vessel to demonstrate effectively the suitability of the screw for oceangoing ships and she ushered in the revolution which led to the abandonment of paddle-wheel propulsion in the ships of both the Royal Navy and the Mercantile Marine.

The Archimedes was built of wood at Millwall by Henry Wimshurst (1804-84) for the Ship Propeller Company, a syndicate formed to further the use of the screw-propeller patented by Francis Pettit Smith on May 31, 1836. Smith had previously built a small screw-driven boat of 6 tons bearing his name. The Archimedes was $125 \mathrm{ft}$. long overall, $106 \mathrm{ft}$. long between perpendiculars, $22 \frac{1}{2} \mathrm{ft}$. beam and drew between $9 \mathrm{ft}$. and $10 \mathrm{ft}$. of water. Her tonnage was 240 tons. Her machinery consisted of a two-cylinder steam-engine driving the propeller shaft through spur gearing. The cylinders were $37 \mathrm{in.}$ in diameter and $3 \mathrm{ft}$. stroke. With steam at $6 \mathrm{lb}$. pressure the engine developed about 80 horse-power. The engine speed was 26 revolutions per minute and the propeller speed 140 revolutions per minute. The first screw fitted was of $7 \mathrm{ft}$. diameter, $8 \mathrm{ft}$. pitch and $8 \mathrm{ft}$. long. This in 1840 was replaced by a double-bladed screw of $5 \frac{3}{4} \mathrm{ft}$. diameter, $10 \mathrm{ft}$. pitch but of greatly reduced length, but various other screw propellers were also tried. Her machinery was made at Greenwich by J. and G. Rennie. The total cost of the vessel was $£ 10,500$.
In accordance with Admiralty instructions early in 1840 , Captain $\mathbf{E}$. Chappell, who had been associated with the Steam Facket Service, took command of her and a series of trials were carried out at Dover between the steam packet Widgeon and the Archimedes. The Widgeon was 162 tons and was the fastest boat on the Dover station. The trials were attended by Thomas Lloyd, who afterwards became the first Engineer-in-Chief of the Navy. The joint report of Chappell and Lloyd dated May 2, 1840, was the first official report made to the Admiralty on screw-propulsion. In it it was stated that "it is evident in these vessels the power of the screw is equal, if not superior to that of the ordinary paddle. wheel. In this respect therefore Mr. Smith's invention may be considered completely successful." After some remarks on the noise and wear of the gearing, the teeth of which were of wood, the report went on to say that "It is, however, in propelling vessels of war that the value of Mr. Smith's invention will probably be experienced. . . . A ship fitted with a screw propeller may be used either as a sailing or a steaming vessel, or as both, if required; for we ascertained by experiment that the engine can be connected and disconnected with ease, and in any weather, in two or three minutes. In carrying a press of sail, the inclination of the ship does not diminish the propelling power of the screw nor lessen the ship's way, as with the ordinary paddle-wheel. The getting rid of the paddle-boxes also leaves the broadside battery altogether clear of obstruction, and in boarding an enemy's vessel would allow of the ships lying close alongside of each other".

Experiments with the Archimedes were also carried out at Bristol by Brunel, and it was through these that he was led to adopt screw-propulsion for the famous Great Britain, the first screw-driven ship to cross the Atlantic.

\section{University Events}

Cambridge.-The Jacksonian professorship of natural philosophy is vacant. The stipend of the professor is $£ 1,200$ a year or, while he holds a fellowship of a college with dividend, $£ 1,000$. The professorship is assigned for this turn to experimental atomic physics and will be associated with the Cavendish Laboratory. Candidates are requested to send their names to the Vice-Chancellor on or before April 11, 1939 , with twelve copies of any statement or testimonial which they desire to submit to the electors.

The Smith's Prizes have been awarded to T. E. Easterfield, of Clare College and H. N. V. Temperley, of King's College; and Rayleigh Prizes to J. Corner, of Peterhouse, D. S. Evans, of King's College, R. A. Rankin, of Clare College and D. B. Schultz, of Magdalene College.

St. Andrews,-Prof. E. Finlay Freundlich, formerly professor in the German University, Prague, has been appointed Napier lecturer in astronomy and director of the new Astronomical Observatory in the United College, St. Andrews. The lectureship owes its institution to a bequest made to the University by the late Miss Scott Lang, daughter of Sir Peter Scott Lang, formerly professor of mathematics in the United College. It was the desire of Sir Peter Scott Isang that the lectureship should bear the name of Napier of Merchiston, one of the early students of the University. 